"Przegląd Prawa Konstytucyjnego" Nr 1 (17)/2014 ------

\title{
Sprawozdanie
}

\section{Międzynarodowa konferencja naukowa La creación jurisprudencial del Derecho a la Salud (Ewolucja prawa do ochrony zdrowia) w ramach II spotkania The Constitutional Law Journal Network (Światowej Sieci Czasopism Prawa Konstytucyjnego), Meksyk, 28-29 listopada 2013 r.}

W dniach 28-29 listopada 2013 r. w Instytucie Badań Prawnych Narodowego Autonomicznego Uniwersytetu Meksyku w Meksyku (Instituto de Investigaciones Jurídicas de la Universidad Nacional Autónoma de México UNAM) odbyła się Międzynarodowa Konferencja Naukowa, której tematem były sprawy związane $\mathrm{z}$ rozwojem i zmianami w regulacjach prawnych prawa do ochrony zdrowia. Konferencja ta była częścią II spotkania The Constitutional Law Journals Network - CLJN - (Światowej Sieci Czasopism Prawa Konstytucyjnego - http://www.revistasconstitucionales.unam.mx/en/ default.htm). Organizatorem konferencji był dr Edgar Corzo Sosa, prezes CLJN, oraz Narodowy Autonomiczny Uniwersytet Meksyku.

W spotkaniu wzięli udział naukowcy z wielu państw, w tym z Brazylii, Peru, Kolumbii, Włoch, Argentyny, Meksyku. Polskę reprezentowała Pani prof. nadzw. dr hab. Sabina Grabowska, która jest redaktorem naczelnym kwartalnika „Przegląd Prawa Konstytucyjnego” wchodzącego, jako jedyne czasopismo z Europy Środkowo-Wschodniej, w skład Światowej Sieci Czasopism Prawa Konstytucyjnego.

Konferencję otworzył dr Edgar Corzo Sosa, witając władze uczelni w osobach J.M. Rektora Narodowego Autonomicznego Uniwersytet Meksyku dr. José Narro Roblesa oraz dyrektora Instytutu Badań Prawnych UNAM dr. Héctora Fixa-Fierro, oraz przedstawicieli nauki, praktyków i studentów. Dr E. Corzo Soza stwierdził, iż prawo do ochrony zdrowia, jako jedno z praw socjalnych, pełni ważną rolę we właściwym funkcjonowaniu państwa i jest 
jednym z najistotniejszych praw człowieka. Prawo to zaliczane jest do kategorii praw socjalnych, z których powinno się korzystać bez względu na jakiekolwiek kryteria. Prawa socjalne stanowią uprawnienia, które gwarantują jednostce podstawowe dobra, niezbędne do godnego życia w społeczeństwie. Stanowią one prawa szczególnego rodzaju, w celu realizacji których państwo ma obowiązek podejmowania działań pozytywnych, pozwalających jednostce na korzystanie $\mathrm{z}$ danego prawa.

Następnie głos zabrał J.M. Rektor UNAM dr José Narro Robles, który podkreślił znaczenie właściwych regulacji prawa do ochrony zdrowia; sam będąc lekarzem, często spotyka się z niejasnościami w tym zakresie i trudnościami wynikającymi z luk w prawie. Stwierdził, że takie właśnie spotkania naukowców - prawników - z różnych środowisk wpływają pozytywnie zarówno na rozwój współpracy naukowej, jak również nawiązywanie kontaktów i dalszych badań, nie tylko naukowych, ale także towarzyskich.

Jako kolejny wystąpił dyrektor Instytutu Badań Prawnych UNAM dr Héctor Fix-Fierro. Zaznaczył, iż inicjatywa dr Edgara Corzo Sosa zasługuje na kontynuację, tym bardziej, że tematyka ochrony i egzekwowania praw socjalnych, w tym i prawa do ochrony zdrowia, jest istotna dla każdego państwa demokratycznego i w interesie władz leży jej właściwe funkcjonowanie i rozwój.

W części naukowej konferencji referenci w swoich wystąpieniach skupili się na opracowaniu prawnego wzorca funkcjonowania prawa do ochrony zdrowia w porządkach prawnych reprezentowanych państw. Za podstawę tych analiz posłużyły regulacje prawne, wyroki sądów bądź trybunałów konstytucyjnych, jak również praktyka i doświadczenia związane z funkcjonowaniem prawa do ochrony zdrowia, zaliczanego do kategorii praw socjalnych. Prawo to posiada cechy szczególne w różnych systemach prawnych, takie jak kwestie związane z: zakupem leków, prawami osób chorych na AIDS, istnieniem odpowiednich miejsc dla świadczenia właściwej opieki zdrowotnej, dostępem do świadczeń zdrowotnych finansowanych ze środków publicznych, bezpiecznymi i higienicznymi warunkami pracy. Problematyka prawa do ochrony zdrowia jako jednego $\mathrm{z}$ praw socjalnych stanowi istotny zakres zainteresowań prawa konstytucyjnego. Ponadto ma wielki wpływ na społeczeństwo i postrzeganie organów władzy przez obywateli. 
Jako pierwszy głos zabrał prof. Andrea Morrone reprezentujący periodyk "Quaderni Costituzionali: Rivista Italiana Di Diritto Costituzionale” i przedstawił sytuację związaną z prawem do ochrony zdrowia we Włoszech. Kolejny referent, dr German Lozano Villegas (periodyk „Revista Derecho del Estado”, Externado Uniwersytet Kolumbii w Bogocie), zapoznał uczestników konferencji z sytuacją w Kolumbii. Prawo do ochrony zdrowia w Meksyku było tematem wystąpienia dr. Edgara Corzo Sosa (periodyk „Cuestiones Constitucionales, Revista Mexicana de Derecho Constitucional”, Narodowy Autonomiczny Uniwersytet Meksyku). Jako ostatni w pierwszej sesji głos zabrał prof. Víctor Bazán z Wydziału Prawa i Nauk Społecznych Katolickiego Uniwersytetu Cuyo (San Juan, Argentyna).

Po wystąpieniu każdego z referentów pozostali uczestnicy konferencji mieli możliwość zadawania pytań. Pierwszy dzień obrad zakończyła uroczysta kolacja.

W drugim dniu obrad uczestnicy konferencji wysłuchali referatów o prawie do ochrony zdrowia: w Brazylii, którego autorem był Ilton Norberto Robl Filho, reprezentujący czasopismo „Revista de la Academia Brasileira de Direito Constitucional”, oraz w Peru, autorstwa Felipe Johana Leóna Floriana (periodyk „Pensamiento Constitucional”), a także w Polsce, który przedstawiła prof. Sabina Grabowska (kwartalnik „Przegląd Prawa Konstytucyjnego").

Ponadto na konferencji przedstawiono dodatkowo dwa referaty związane tematycznie z głównym tytułem konferencji. Pierwsze wystąpienie dotyczyło praw osób niepełnosprawnych i zostało zaprezentowane przez dr Ingrid Brena Sesma z Instytutu Badań Prawnych UNAM oraz Luz Helenę Orozco y Villę z Sądu Najwyższego. Drugie wystąpienie dr. Fernando Cano Valle z Instytutu Badań Prawnych UNAM przybliżyło kwestie związane ze zdrowiem, uzależnieniami oraz prawami człowieka.

Na zakończenie obrad głos zabrał koordynator konferencji, dr Edgar Corzo Sosa. W swoim wystąpieniu podziękował wszystkim osobom za udział $\mathrm{w}$ konferencji, za referaty, za głosy w dyskusji oraz zainteresowanie zaproponowaną tematyką. Stwierdził, iż postara się, aby kolejna konferencja była równie ciekawa. Ponadto poinformował, że referaty zostaną opublikowane w najbliższym możliwym terminie. 
Pomiędzy sesjami konferencji miało również miejsce spotkanie Prezydium Światowej Sieci Czasopism Prawa Konstytucyjnego (CLJN). Głównym celem spotkania było umocnienie współpracy naukowej pomiędzy czasopismami wchodzącymi w skład CLJN.

Uczestnicy spotkania zajęli się sprawami związanymi z coraz częstszą praktyką wielokrotnego publikowania tych samych tekstów przez naukowców. Prof. Andrea Morrone (Włochy) stwierdził, iż należy zapobiegać takim praktykom. Będzie to możliwe dzięki wzajemnemu informowaniu się redakcji czasopism o publikowanych lub przyjętych do druku tekstach, jak również nałożeniu na autorów publikacji obowiązku składania oświadczeń o tym, że tekst nie jest przedmiotem postępowania publikacyjnego w innym czasopiśmie. Ponadto Ilton Norberto Robl Filho (Brazylia) zgłosił propozycję utworzenia bazy tekstów w ramach witryny CLJN, dzięki której łatwiejsze stanie się sprawdzenie, czy dany tekst był już publikowany.

Dr Edgar Corzo Sosa (Meksyk) przybliżył sprawy związane ze znaczeniem logo CLJN, które odzwierciedla akademickie więzi między czasopismami - członkami CLJN - oraz z jego wykorzystywaniem i rozpowszechnianiem przez czasopisma wchodzące w skład CLJN. Stwierdził, że logo powinno być umieszczane na stronach internetowych czasopism, a także na wszystkich publikacjach i projektach naukowych członków CLJN. Zachęcił również do promocji CLJN w swoich środowiskach naukowych.

Kolejnym tematem poruszonym na spotkaniu były sprawy związane z możliwością publikacji na stronie CLJN aktualności z działalności poszczególnych jej członków. Dzięki temu, stwierdził German Lozano Villegas (Kolumbia), możliwe będzie wsparcie w realizowaniu projektów prowadzonych przez członków CLJN i przyczyni się to bezpośrednio do rozwoju nauki prawa konstytucyjnego.

Sprawy związane z uczestnictwem i wspólnym referatem CLJN w IX Światowym Kongresie Prawa Konstytucyjnego nt. Wyzwania konstytucyjne: globalne i lokalne, organizowanym przez Międzynarodowe Towarzystwo Prawa Konstytucyjnego (The International Association of Constitutional Law IACL) oraz Wydział Prawa Publicznego i Międzynarodowego Uniwersytetu w Oslo w dniach 16-20 czerwca 2014 r. przedstawiła prof. Sabina Grabowska (Polska). Zasugerowała również wybór panelu nr 5 nt. Sądowe i pozasądowe dyskusje o Konstytucji. Propozycję przyjęto jednomyślnie. 
Z powodu zbliżającego się stulecia Konstytucji Meksyku dr Edgar Corzo Sosa zaproponował udział CLJN w projekcie związanym z organizacją tego wydarzenia. Każdy z członków CLJN zgłaszał propozycje działań. Prof. Sabina Grabowska zgłosiła propozycję wydania okolicznościowego numeru „Przeglądu Prawa Konstytucyjnego” w języku hiszpańskim, którego tematyka dotyczyłaby podobieństw i różnic konstytucyjnych przepisów Polski i Meksyku w ujęciu komparatystycznym. Propozycję przyjęto z uznaniem.

Następnie poddano pod dyskusję aplikacje kandydatów na nowych członków CLJN. Kandydatom przedstawiono wymogi, które powinni spełnić, aby możliwe było przyjęcie ich do Światowej Sieci Czasopism Prawa Konstytucyjnego.

Na zakończenie spotkania dr Edgar Corzo Sosa podziękował członkom CLJN za przybycie oraz wyraził nadzieję na dalszą, równie owocną współpracę.

W ostatnich dniach pobytu w Meksyku organizatorzy zaprosili uczestników konferencji na wycieczkę, podczas której zwiedzono ruiny Tlatelelko, sanktuarium Matki Boskiej w Gwadelupie oraz zespół piramid w Teotihuacan.

Sabina Grabowska Uniwersytet Rzeszowski 